\title{
RESENHA
}

\section{CHEVITARESE, A. L. O espaço rural da Pólis Grega: o caso ateniense do período clássico. Rio de Janeiro: Fábrica de Livros: Senai, 2001.}

\section{Lourdes Madalena Gazarini Conde Feitosa ${ }^{1}$}

Este livro, do historiador e arqueólogo André Leonardo Chevitarese, traz significativas contribuições para a compreensão do espaço rural ateniense. Trata-se de um estudo preocupado em perceber como o espaço rural (khóra) foi ocupado, explorado e representado na Atenas clássica, priorizando a participação política da população rural ática na democracia. Para a compreensão da dinâmica democrática ateniense, é estabelecida uma relação com a organização rural, porque a terra era de posse exclusiva daqueles considerados cidadãos e seus proprietários desfrutavam de um importante status. O pesquisador atém-se a diversos aspectos relacionados a esse universo como a evidência topográfica, o clima, a fauna, as atividades agrícolas, os habitantes rurais e o tipo de mão de obra utilizada, bem como a integração desses indivíduos com o espaço urbano. Seguindo uma nova tendência de utilizar, em conjunto, documentos literários, arqueológicos, epigráficos e iconográficos nas investigações históricas, esta analise confronta visões literárias àquelas apresentadas em vasos áticos de figuras vermelhas, resultando em uma leitura crítica e inovadora sobre o tema. É verificada uma forte relação entre o sentido da ocupação e da exploração da khóra Ática e o seu impacto na construção das bases sociais, políticas, econômicas e ideológicas da pólis ateniense. Seria por meio de sua atividade política e econômica que o cidadão tornar-se-ia, pelo menos em nível teórico, livre, independente e apto para agir e intervir nas decisões públicas. Na análise documental, verificou-se que as informações por meio dos textos diferenciam-se daquelas encontradas nas fontes arqueológicas: enquanto a primeira sugere uma exploração rural homogênea, em virtude da representação ideológica democrática, a segunda permite perceber uma heterogeneidade nos assentamentos rurais. Para compreender essas diferentes informações, Chevitarese analisou as variações geológicas e pluviométricas gregas, tanto do período clássico como da época atual, o que lhe possibilitou verificar como a composição acidentada e pedregosa do solo e as poucas chuvas ocasionavam consideráveis perdas agrícolas, fato que resultou na adoção de estratégias diferenciadas pelos agricultores gregos, atestadas principalmente em fontes epigráficas. A tática reputada como ideal para suavizar os riscos de perdas, reconhecida por todos os agricultores, era o fracionamento das suas terras ao longo do território. Para os cidadãos ricos, a viabilidade desse modo de exploração fragmentado dava-se por meio de casamentos entre membros de famílias ricas, de herança e da compra de terras, o que favorecia aos proprietários fundiários absenteístas diminuir suas perdas agrícolas, tão comuns na Ática. Essa prática capacitava os agricultores, particularmente os médios e grandes proprietários, a proverem-se dos riscos eminentes da falta de alimentos. Um outro diferencial na exploração agrícola estaria $n$ a prática de trabalho adotado. Ao contrário de generalizações apresentadas com freqüência acerca do uso constante de escravos por

\footnotetext{
${ }^{1}$ Doutora em História Cultural pelo IFCH/UNICAMP. Endereço: Rua Antônio Molina, 1- 80, Jd. Marambá. CEP $17030-670$ Bauru, SP. Telefone: (14) 230-5560. E-mail: luconde@ travelnet.com.br.
} 
agricultores atenienses, Chevitarese defende que esse tipo de mão de obra seria comum e largamente utilizado em grandes propriedades, ao menos durante o terceiro século a.C., embora também pudesse ser paralelo ao trabalho assalariado livre, em épocas de safra. Já para as pequenas e médias propriedades, é considerado o emprego de parentes, vizinhos, amigos e trabalhadores assalariados livres, como um contingente significativo de força de trabalho na agricultura da região, pois esses proprietários não dispunham de capitais excedentes 98para investir e manter escravos ao longo do ano. $\mathrm{O}$ direito à propriedade, como uma exclusividade do corpo cívico, impediria a posse da terra por estrangeiros, justificando a reduzida presença de metecos na khóra ática. A participação das comunidades rurais na democracia ateniense dar-se-ia por meio da atuação dos indivíduos no demos. Essa afirmação constitui-se em uma das novidades do estudo, que salienta esse espaço como um importante veículo para a organização e o exercício da democracia ateniense. A acepção de dêmos como aldeia, significado até então pouco explorado, ao lado de outros como conjunto de cidadãos e povo comum, valoriza-o como o ambiente político de excelência para o desenvolvimento dessa democracia. Chevitarese defende que é em seu interior que o agricultor irá construir as suas relações pessoais, fundamentais para a sua proteção e segurança, tanto no sentido da luta diária estabelecida contra a natureza, como para conter possíveis abusos praticados por cidadãos ricos e poderosos. Ou seja, é pela participação no dêmos que $o$ ateniense adquire a sua cidadania e se torna apto para atuar na pólis. Contudo, nos textos antigos do período clássico, é notada uma descrição preconceituosa do espaço rústico, sendo o homem rural caracterizado como grosseiro, ignorante, sem refinamento social, gosto pela política ou pelos costumes da ásty (espaço urbano). No confronto entre essas obras literárias e as cenas rurais da cerâmica ática de figuras vermelhas do período clássico, presentes no Corpus Vasorum Antiquorum e pela primeira vez utilizadas sistematicamente por um estudioso, o autor identifica visões antagônicas. A representação literária pessimista é substituída por imagens iconográficas de um ambiente rural repleto de vida, de trocas e de tensões políticas e sociais. Um universo campestre caracterizado pela diversidade de ocupação, de organização dos camponeses, de suas relações com os dêmoi (aldeias), com suas propriedades fundiárias e com a própria ásty. Essa conotação positiva não o impossibilita, entretanto, de perceber uma drástica redução das cenas envolvendo o mundo rural nas representações iconográficas dos vasos áticos, a partir da segunda metade do século quinto, chegando praticamente a sumir no século seguinte. Para Chevitarese, a construção da imagem negativa do rústico apresentada em obras literárias e de seu gradativo desaparecimento na pintura, deve-se ao fato de Atenas ter assumido um papel de destaque no cenário social, econômico, político e ideológico grego após as guerras púnicas e de sua construção como um império marítimo. A cidade passaria, assim, a adquirir, segundo os olhos dos autores e artistas antigos gregos, uma supremacia sobre o mundo rural, fundamentando a imagem representada ou justificando a sua ausência. É por meio desse extenso e variado conjunto documental que o autor desenvolve uma análise complexa e plural do espaço rural ateniense e da participação na experiência democrática também por aqueles que integravam as comunidades rurais. A riqueza e diversidade apresentadas foram possíveis pelo confronto das fontes literárias com as arqueológicas e pela inquietação do pesquisador em compreender a organização ateniense além da visão estereotipada dos grupos aristocráticos que ocupavam o universo da ásty. Trata-se de um inovador estudo da Arqueologia e História rural da Antigüidade no Brasil, que oferece ao público brasileiro a oportunidade de ter um conhecimento mais profundo acerca do tema em uma linguagem clara e estimulante. 